\section{Category}

Synthesis of

Materials and

Unnatural Products

\section{Key words}

corannulenes

flash vacuum pyrolysis

polycyclic aromatic hydrocarbons

L. T. SCOTT*, M. M. HASHEMI, D. T. MEYER, H. B. WARREN (UNIVERSITY OF NEVADA, RENO, USA)

Corannulene. A Convenient New Synthesis

J. Am. Chem. Soc. 1991, 113, 7082-7084.

\title{
Synthesis of Corannulenes Revisited
}<smiles>COC(=O)CC(=O)CC(C)C</smiles><smiles>COC(=O)C1=C2C(=C(C(=O)OC)C1=O)c1cccc3cccc2c13</smiles><smiles>COC(=O)c1ccc(C(=O)OC)c2c1-c1cccc3cccc-2c13</smiles>

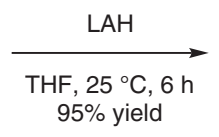<smiles>OCc1ccc(CO)c2c1-c1cccc3cccc-2c13</smiles>
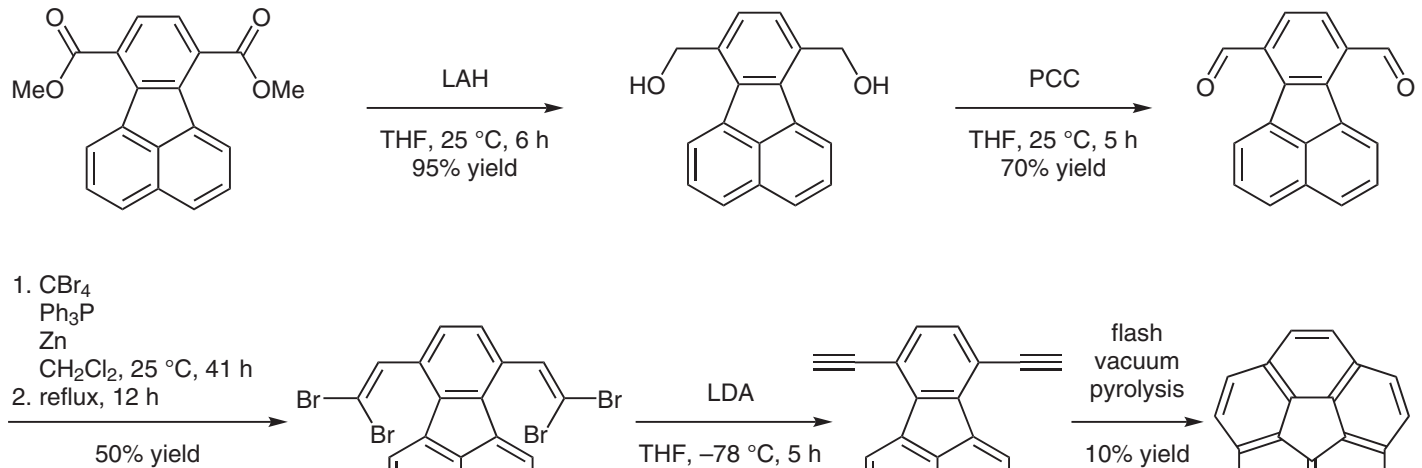<smiles>BrC(Br)=CC1=CC=C2C=C(Br)C(Br)=C1C1=CC=Cc3cccc1c32</smiles>

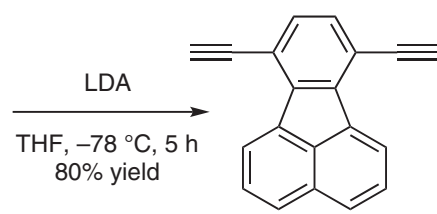
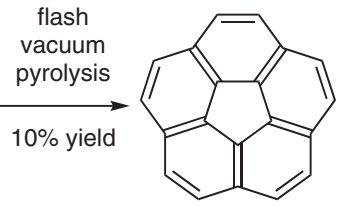

Significance: In 1991, Scott and co-workers reported a convenient synthesis of corannulene. Corannulenes are interesting because of their unique optoelectronic properties arising from their bowlshaped structure. The production of corannulene is currently possible on a kilogram scale, and corannulene has found many applications in materials.
Comment: Flash vacuum pyrolysis of the tetrabromide intermediate also resulted in corannulene. The unprecedented carbon NMR spectrum of corannulene exhibited three peaks. 